\title{
THE COMPOSITION OF SAPPHIRINE FROM SALVADOR, BAHIA, AND CONDITIONS OF ITS FORMATION
}

\author{
JOHN G. STORMER JR.*
}

\begin{abstract}
RESUMO Safirina é um mineral raro de rochas metamórficas de alto grau. Duas amostras de Salvador, Bahia, foram analisadas por meio de microssonda eletrônica juntamente com os minerais associados. Essas amostras são semelhantes a outras descritas na literatura, mas possuem um teor em Fe muito alto. Quase metade desse Fe deve substituir o Al. Evidências químicas, petrográficas e de campo indicam que a safirina formou-se pela reação de sílica metassomática com espinélio num corpo de bronzitito (rocha formada principalmente de ortopiroxênio). Maior silicatização transformou a safirina em cordierita, em algumas partes. A temperatura indicada pelo teor em $\mathrm{Al}_{2} \mathrm{O}_{3}$ dos ortopiroxênios é de aproximadamente $1000^{\circ} \mathrm{C}$, e a pressão é estimada entre 5 e $8 \mathrm{~kb}$.
\end{abstract}

ABSTRACT Analyses of two sapphirine specimens from Salvador, Bahia, Brazil along with partial analyses of some associated minerals were made by electron microprobe. These sapphirines are similar to other analysed specimens, but are among the most iron rich $(9.2$ and $9.8 \mathrm{wt} \%$ total iron as $\mathrm{FeO}$ ). Nearly half of this iron must be present as $\mathrm{Fe}^{+3}$ substituting for Al. Field petrographic and chemical evidence suggests that the sapphirine developed by adition of silica to a spinel bearing bronzitite body. Further introduction of silica apparently produced reaction of sapphirine to cordierite in parts of the body. The temperature of formation given by $\mathrm{Al}_{2} \mathrm{O}_{3}$ content of the orthopyroxene was near $1000^{\circ} \mathrm{C}$; the pressure is estimated to be in the range 5 to 8 kilobars.

INTRODUCTION Sapphirine is an unusual mineral of high grade metamorphic rocks (granulite facies). It characteristically occurs in assemblages poor in silica but rich in both aluminum and magnesium. Sapphirine is generally considered to be a rare mineral but several new occurences have been discovered in recent years among them the occurence at Salvador, Bahia (Allard and Fujimori, 1966). It is probably more common than previously thought, and should be expected in rocks of favorable composition in any granulite terrain.

The simplest formula unit can be written $\mathrm{Mg}_{2} \mathrm{Al}_{4} \mathrm{SiO}_{10}$. The silicon and two aluminum ions in this unit would be found in tetrahedral sites, and the remaining two aluminum and magnesium ions in octahedral sites according to the structure analysis made by Moore (1969). The sample analysed by Moore and most other natural samples have a greater number of $\mathrm{Al}$ ions substituting for $\mathrm{Mg}$ and $\mathrm{Si}$, than this simple formula, (Deer, et al., 1963, Schreyer and Seifert, 1969) and more complex formula units have been proposed to reflect this common substitution.

The sapphirine described by Allard and Fujimori (1966) occurs in a roughly spherical mass of phlogopite and spinel bearing bronzitite. This mass, about $5 \mathrm{~m}$ in diameter, is found in an outcrop of hypersthene granulite near the shore, $150 \mathrm{~m}$ east of the Bacia das Moças, Salvador, Brazil. Similar masses of bronzitite enclosed in hypersthene granulite occur throughout the Salvador area and are believed to be of sedimentary origin. Quartz-feldspathic granulite, granite and associated aplite and pegmatite dikes also occur in the immediate area.

*Dept. of Geology, University of Georgia, Athens, Georgia 30602, EUA 
Sample description The different samples were selected for analysis, each seemed to be representative of the two most distinctive sapphirine assemblages. Number 100, from near the center of the mass, consists predominantly of coarse-grained bronzite and phlogopite with minor amount of spinel. The grains of spinel have rims of sapphirine surrounding them.

Number 101 is from nearer the outside of the mass. Here spinel is completely absent, orthopyroxene and phlogopite still predominate but sapphirine and cordierite occur as symplectitic intergrowths within large grains of hypersthene. The intergrowths have the appearance of fine bands of cordierite or sapphirine $10-50 \mu$ in width in generally linear or plumose patterns. In places the proportions of sapphirine, (or cordierite) in these intergrowths reaches $50 \%$. Although the appearance suggests some structural control, solution or reaction along cleavage planes is not obvious. The composition of the symplectite varies systematically across the section $(2 \mathrm{~cm})$ the hypersthene host crystals remain the same but on one side the intergrowth is composed entirely of sapphirine; on the other side the intergrowth is composed of cordierite; while in the intermediate area cordierite appears to be replacing sapphirine. Some of the bands or stringers of sapphirine are completely replaced by cordierite, some still contain isolated sections or islands of sapphirine.

Although no attempt was made in this study to accurately determine the optical properties, the two samples of sapphirine were apparently identical and within the range of commonly reported properties (Deer et al, 1963). The only apparent differences between the two sapphirine samples were the textures and the associated minerals. A paper describing the field relationships and microscopic observations in more detail is being prepared by Dr. G. O. Allard and myself.

Mineral compositions Sapphirine, orthopyroxene, spinel and cordierite were analysed for the elements listed in Tab. I, using a Material Analyses Co. Model 400S electron microprobe. Although these are partial analyses, the totals, being near $100 \%$, indicate that any other elements may be present only in very minor amounts. Analysis conditions were: accelerating voltage $15 \mathrm{kV}$; sample current $0.05 \mu \mathrm{A}$ on brass; RAP, PET, and Lif crystal spectrometers; sealed and thin window flow proportional counters as appropriate to detect $K_{\alpha}$ radiation; counting time $20 \mathrm{sec}$. using beam current stabilizer. Various analysed silicate minerals were used as standards. All analyses were corrected for background and drift using a computer program written by myself. The empirical correction factors of Albes and Ray (1970) were applied for the sapphirine and spinel where absorbtion and other effects were significant. In other cases standards were sufficiently close in composition to the analysed material. All calculations were carried out to four significant figures and subsequently rounded in Tab. I to values approximating the estimated accuracy:

SAPPHIRINE Although there are slight differences all three analyses of sapphirine from these samples are essentially the same. In general the analyses are very similar to those of other natural sapphirines. The iron content, however, is near the highest previously reported values. The analyses in Tab. I show a deficiency of silica as compared to the simple formula $(\mathrm{MgFe})_{2} \mathrm{Al}_{4} \mathrm{SiO}_{10}$. This deficiency is also common in other analysed natural sapphirines (Deer et al., 1963; Wilson and Hudson, 1967). Substitution of Al for Si in tetrahedral sites and concurrent substitution of $\mathrm{Al}$ and other trivalent cations for $\mathbf{M g}$ and $\mathrm{Fe}^{+2}$ on other sites has been considered to account for most of the compositional variation of both natural and synthetic sapphirine (Deer et al., 1963., Schreyer and Seyfert, 1969). If the deficiency of silica in these analyses is made up by $\mathrm{Al}$ in tetrahedral sites as shown in Tab. 1, then a considerable portion of the iron must be present as $\mathrm{Fe}^{+3}$ to maintain 
Table I - Mineral analyses

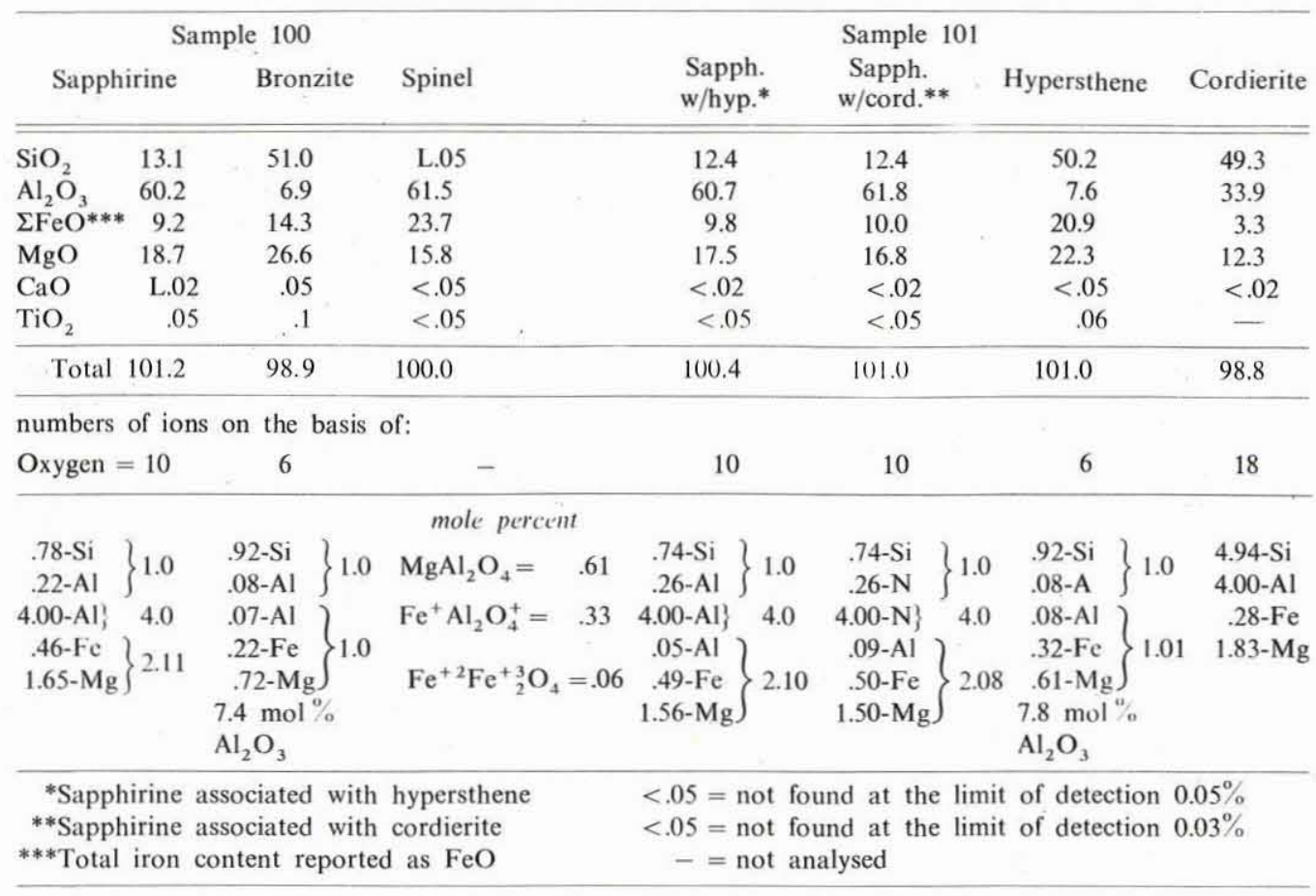

the charge balance (nearly $50 \%$ in sample 100 ). Unfortunatly $\mathrm{Fe}^{+2}$ and $\mathrm{Fe}^{+3}$ cannot be determined separately by electron microprobe techniques, but other reported analysis commonly show significant $\mathrm{Fe}_{2} \mathrm{O}_{3}$ contents. In several cases $\mathrm{Fe}^{+3}$ accounts for about $50 \%$ of the total iron content (compare Meng and Moore, 1972 Tab. III).

HYPERSTHENE The Mg-Fe ratios of the orthopyroxene from the two samples is quite different. This is especially striking since the sapphirine is essentially of constant composition. This can easily be seen in the lower portion of Fig. 1. The orthopyroxene composition appears to change as the assemblage changes its mineralogical composition. There was no noticeable zoning or compositional gradients within grains of orthopyroxene but there was some variability between grains and the averages in Tab. I and Fig. 1 represent a spread of values in $\mathrm{Mg}$ and $\mathrm{Fe}$. The ranges of values from the two samples, however, do not overlap and an overwhelming majority of points lie close to the average value. Another interesting feature of these analyses is the high alumina content, which remains nearly the same in both samples.

SPINEL The mole proportions of cations in the spinel analysis were recalculated to the spinel and hercynite molecules. The small amount of $\mathrm{Fe}$ remaining was calculated as magnetite. The results of this procedure show that the spinel phase in sample 100 is predominantly a spinel-hercynite solid solution with an almost negligible amount of magnetite.

CORDHERITE The total of the analyses in Tab. I would permit a small amount of water in the composition of this cordierite. $1.5-2.5 \% \mathrm{H}_{2} \mathrm{O}$ is common in natural cordierites 

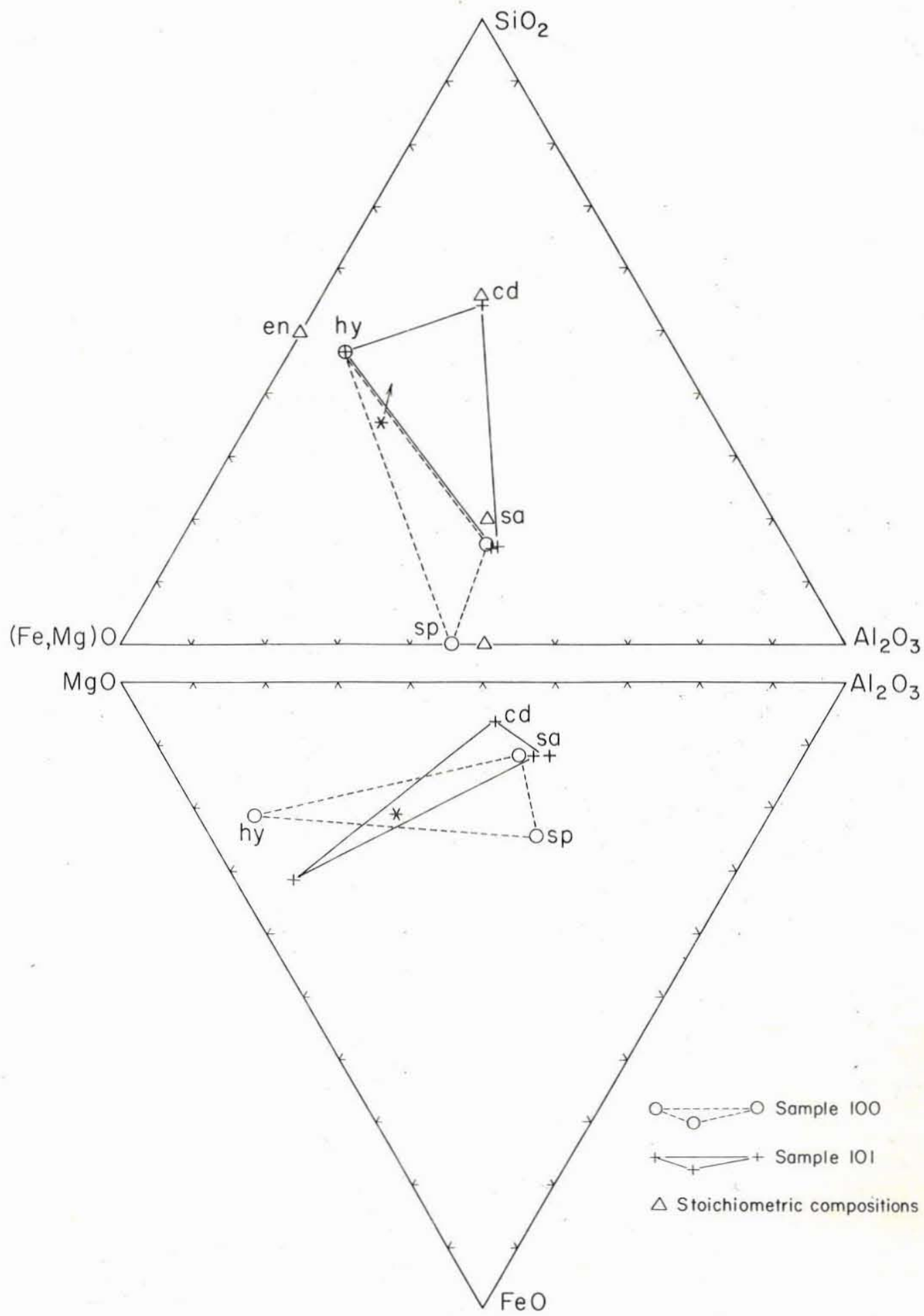

Figure 1 - Compositions of the analysed minerals. Ideal mineral compositions indicated by small triangle. Assumed initial composition is shown by a star with path of silica metasomatism indicated by an arrow. $c d$, cordierite; $h y$, hypersthene (bronzite); $s a$, sapphirine; $s p$, spinel 
(Deer et al., 1963). In all other respects the cordierite is entirely normal. The common preference of cordierite for $\mathrm{Mg}$ vs. Fe relative to coexisting minerals is easily seen.

PETROGENESIS The field relations of the samples and the textural relationship of the minerals within each sample suggest that sapphirine was formed by the reaction of spinel with silica:

$$
\underset{\text { spinel }}{2 \mathrm{MgAl}_{2} \mathrm{O}_{4}}+\mathrm{SiO}_{2}=\underset{\text { sapphirine }}{\mathrm{Mg}_{2} \mathrm{Al}_{4} \mathrm{SiO}_{10}}
$$

With the introduction of more silica sapphirine was converted to cordierite:

$$
\underset{\text { sapphirine }}{\mathrm{Mg}_{2} \mathrm{Al}_{4} \mathrm{SiO}_{10}}+4 \mathrm{SiO}_{2}=\underset{\text { cordierite }}{\mathrm{Mg}_{2} \mathrm{Al}_{4} \mathrm{Si}_{5} \mathrm{O}_{18}}
$$

The assemblage in sample 100 with sapphirine rims surrounding the spinel corresponds to reaction 1. And the replacement of sapphirine by cordierite in sample 101 corresponds to reaction 2. The course of these reactions is also shown in Fig. 1. The approximate composition of sample 100 is indicated by a star and the effect of adding silica by an arrow toward the silica apex. An interesting feature of the analyses as shown in the lower portion of Fig. 1 is that the orthopyroxene also changes its composition with respect to $\mathrm{Mg}$ and $\mathrm{Fe}$ as reactions 1 and 2 progress. Note that the hypersthene in sample 101 is more iron rich than in sample 100. Magnesium is apparently preferentially distributed into sapphirine with respect to spinel and into cordierite with respect to sapphirine. As the spinel reacts to sapphirine the hercynite component of the spinel reacts with the enstatite component of the orthopyroxene and silica to produce more magnesian sapphirine.

$$
\underset{\text { hercynite }}{2 \mathrm{FeAl}_{2} \mathrm{O}_{4}}+\underset{\text { enstatite }}{2 \mathrm{MgSiO}_{2}}+\mathrm{SiO}_{2}=\underset{\text { sapphirine }}{\mathrm{Mg}_{2} \mathrm{AlSiO}_{10}}+\underset{\text { ferrosilite }}{2 \mathrm{FeSiO}_{3}}
$$

And, in the same way, the iron sapphirine component reacts with the enstatite to produce cordierite and a more iron-rich orthopyroxene.

$$
\begin{aligned}
& \mathrm{Fe}_{2} \mathrm{Al}_{4} \mathrm{SiO}_{10}+2 \mathrm{MgSiO}_{3}+4 \mathrm{SiO}_{2}=\mathrm{Mg}_{2} \mathrm{Al}_{4} \mathrm{Si}_{5} \mathrm{O}_{18}+2 \mathrm{FeSiO}_{3} \\
& \text { Fe-sapphirine enstatite cordierite ferrosilite }
\end{aligned}
$$

The effect of adding silica to the bronzitite was to affect a progressive silicification of the $\mathrm{Mg}-\mathrm{Al}$ bearing minerals, and, as a consequence of the increasing preference for $\mathrm{Mg}$ with respect to $\mathrm{Fe}$, the orthopyroxene became more iron rich.

The original bronzite-phlogopite-spinel assemblage was quite silica poor. But abundant silica was present in the surrounding rocks as demonstrated by the granites, pegmatites, and aplite dikes. The bronzitite must have been relatively impermeable to this silica since the assemblage characteristic of the first reaction is still present in sample 100 from near the center while the assemblage characteristic of the second, more silica rich, reaction is present in sample 101 from nearer the outside.

The origin of sapphirine by introduction of silica into an aluminum rich rock of ultrabasic composition is a process which has been suggested for many of the other sapphirine occurences such as those of West Greenland (Heard, et al., 1969) and Australia (Wilson and Hudson, 1967). This type of paragenesis.must be contrasted with occurrences where sapphirine and quartz occur together in stable association, apparently, as the high pressure equivalent of cordierite. These have been described by Dalwitz (1968), Morse and Talley (1971), and Chatterjee and Schreyer (1972). 
The occurrence of sapphirine in Bahia appears to be a result of silica metasomatism of an originaly silica poor assemblage of bronzite-phlogopite-spinel. All the minerals of this assemblage, and the metasomatic products (except phlogopite), correspond to phases in the system $\mathrm{MgO}-\mathrm{Al}_{2} \mathrm{O}_{3} \mathrm{SiO}_{2}$ (allowing for $\mathrm{FeO}$ in the natural equivalents). There is a considerable amount of experimental data available on this system, some of which may be used to obtain some indication of the pressures and temperatures which produced these rocks.

A very good estimate of temperature can be made using the data of Anastasiou and Seifert (1972) on the solubility of $\mathrm{Al}_{2} \mathrm{O}_{3}$ in orthopyroxene. The two analyses of orthopyroxene in Tab. I show approximately $7 \mathrm{wt} \% \mathrm{Al}_{2} \mathrm{O}_{3}$. If this value is compared with the experimental results diagramed in Figs. 4, 6, and 8 of Anastasiou and Seifert it indicates a temperature about $1000^{\circ} \mathrm{C}$. The temperature indicated by Anastasiou and Seifert data and its variation with pressure are shown in Fig. 2. Because their experiments were done under condition where $\mathrm{P}\left(\mathrm{H}_{2} \mathrm{O}\right)=\mathrm{P}($ total $)$, their sapphirine reacted to cordierite + + spinel below $3.5 \mathrm{~kb}$ and the upper limit of their data is $5 \mathrm{~kb}$. But, since the water pressure should not directly affect the orthopyroxene or the sapphirine, this temperature curve can probably be extrapolated for pressures between 1 and $10 \mathrm{~kb}$, so long as the coexisting aluminous phase is sapphirine. The effect of pressure in any case is very small. (We would, however, expect the $\mathrm{Al}_{2} \mathrm{O}_{3}$ contents of orthopyroxene to be different with different coexisting aluminous assemblages). The most serious problem in applying this geothermometer to natural assemblages is the effect of the iron content of the pyroxene on the solubility of alumina. Anastasiou and Seifert discuss the problem but give no quantitative solution. There is no firm theoretical or empirical evidence to suggest just what the effect would be for the assemblages and pressure ranges with which we are concerned. If we assume that the difference in alumina content of the two analysed pyroxenes is due only to enhancement of the $\mathrm{Al}_{2} \mathrm{O}_{3}$ solubility by $\mathrm{Fe}$ for $\mathrm{Mg}$ substitution, the $\mathrm{Al}_{2} \mathrm{O}_{3}$ content can then be linearly extrapolated back to pure enstatite. There it has a value of $5.1 \mathrm{wt} \%$ which is equivalent to a temperature of about $950^{\circ} \mathrm{C}$. It is probably safe to estimate a temperature of $1000 \pm 50^{\circ} \mathrm{C}$ for this sapphirine bearing bronzitite.

Estimates of pressure for this assemblage can be made by considering the conditions under which cordierite and sapphirine can coexist. At 900 to $1000^{\circ} \mathrm{C}$ cordierite breaks down at pressures of 8 to $11 \mathrm{~kb}$ to assemblages of sapphirine enstatite + quartz or enstatite + sillimanite + quartz (Newton, 1972) and sapphirine will break down to cordierite and spinel at low pressures. The problem with this approach is that cordierite stability is greatly affected by the amount of water which enters its structure (much like the water in zeolites). For instance anhydrous cordierite breaks down to sapphirine and quartz (reaction 2 in reverse) at pressures of about $8.5 \mathrm{~kb}$ at $1000^{\circ} \mathrm{C}$ whereas hydrous cordierite is apparently stable up to 10 or $11 \mathrm{~kb}$ (Newton, 1972). Under conditions of $\mathrm{P}\left(\mathrm{H}_{2} \mathrm{O}\right)=\mathrm{P}($ total) sapphirine breaks down to spinel + hydrous cordierite at pressures near $3.5 \mathrm{~kb}$ (Fawcett and Yoder, 1966). However, it is apparently stable down to atmospheric pressure under dry conditions (relative to an anhydrous cordierite).

Using the free energy data of Bird and Anderson (1972) for hydrous cordierite, and a sorbtion energy of about $2.5 \mathrm{kcal}$ per mole of water, a very rough free energy value for sapphirine can be obtained from Newton's (1972) curve for reaction (1). Further calculation then shows that the reaction:

$$
\underset{\text { sapphirine }}{5 \mathrm{Mg}_{2} \dot{\mathrm{Al}}_{4} \mathrm{SiO}_{10}}=\underset{\text { cordierite }}{\mathrm{Mg}_{2} \mathrm{Al}_{4} \mathrm{Si}_{5} \mathrm{O}_{18}}+\underset{\text { spinel }}{8 \mathrm{MgAl}_{2} \mathrm{O}_{4}}
$$




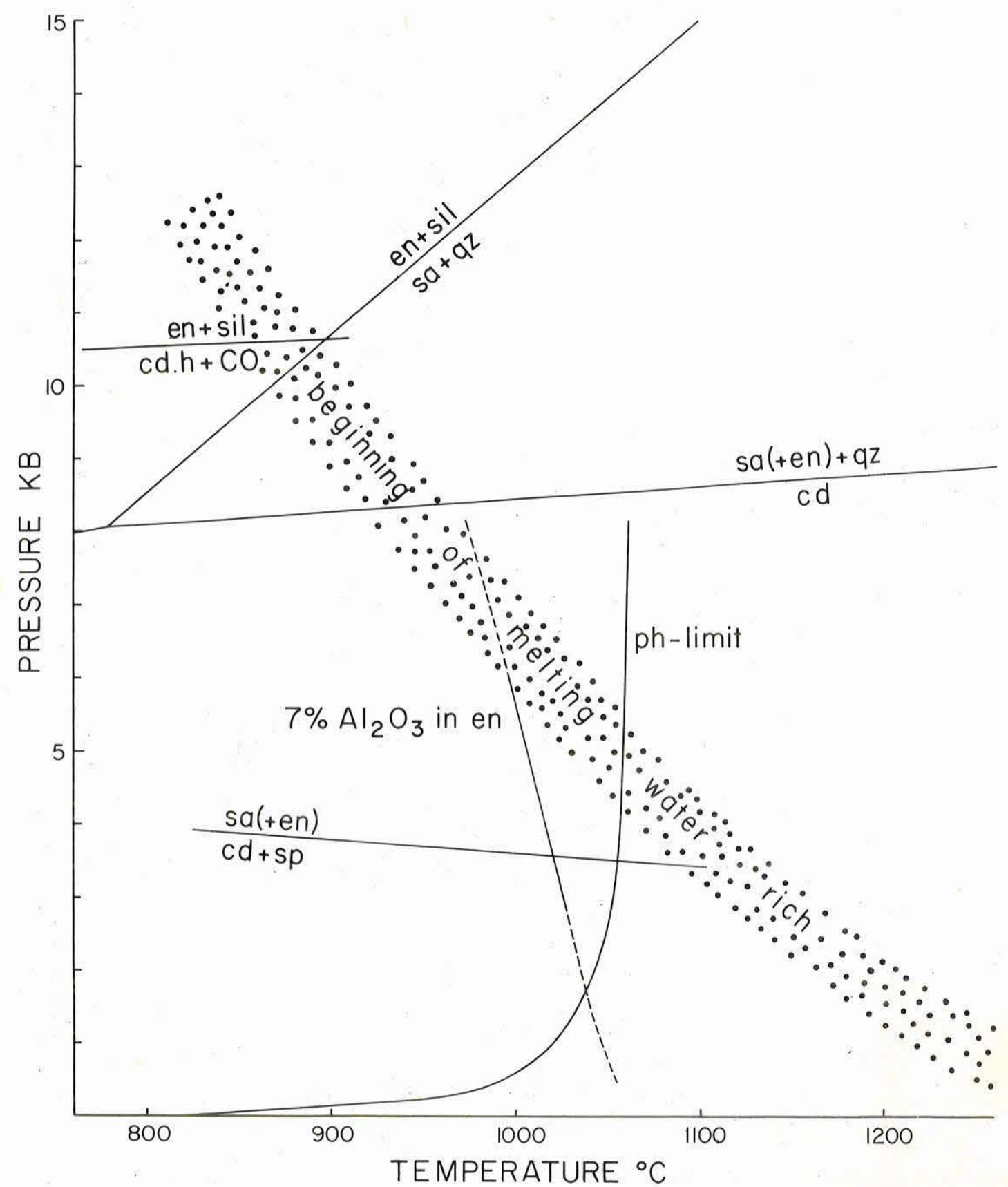

Figure 2 - Stability relationships of sapphirine, cordierite and associated minerals. $c d \cdot h$, hydrous cordierite; $c d$, anhydrous cordierite; $p h$, phlogopite; $e n$, enstatite; $s a$, sapphirine; $s p$, spinel ; $q z$, quartz. (After Newton, 1972; Fawcett and Yoder, 1966; Yoder, and Eugster, 1954; Anastasiou and Seifert, 1972) 
should have a strongly positive free energy, i.e., sapphirine should be stable at $1000^{\circ} \mathrm{C}$ and atmospheric pressure. This is also confirmed by the fact that sapphirine can be synthesized at $1 \mathrm{~atm}$. from dry mixtures of the oxides (Deer, et al., 1963).

The problem of determining the stability field of a natural cordierite is compounded by the fact that cordierites can apparently take on or discharge water relatively rapidly (Schreyer and Yoder, 1964). The water in the analysis of a natural cordierite probably does not represent the amount present at the high temperature equilibrium. But, in the assemblage we are considering here, there is some evidence to suggest that the environment was not entirely dry, although $\mathrm{P}\left(\mathrm{H}_{2} \mathrm{O}\right)$ did not necessarily equal total pressure. The primary evidence is the presence of abundant phlogopite without any evidence of its breaking down. The P-T curve for phlogopite break down $\left[\mathrm{P}\left(\mathrm{H}_{2} \mathrm{O}\right)=\mathrm{P}(\right.$ total $\left.)\right]$ is shown in Fig. 2 (Yoder and Eugster, 1954). The presence of iron, as in these samples, would tend to lower the temperatures somewhat, depending upon the oxygen fugacity (Wones and Eugster, 1965). Estimates based on this work suggest that the water pressure would have to be well over $2 \mathrm{~kb}$ at $1000^{\circ} \mathrm{C}$. The granite, pegmatite and aplite dikes, as well as amphibole and biotite in surrounding rocks, also suggest that some water was present. Hydrous cordierite can apparently retain its water even under conditions where $\mathrm{P}\left(\mathrm{H}_{2} \mathrm{O}\right)$ does not equal total pressure (Newton, 1972, p. 412). It seems reasonable, then, to assume that stability fields based on hydrous cordierite are applicable to the sapphirine-bearing assemblage discussed here. This would place the minimum pressure near $4 \mathrm{~kb}$ and the maximum near $10 \mathrm{~kb}$. The beginning of melting would also place a constraint on temperature and pressure as shown in Fig. 2. At $1000^{\circ} \mathrm{C}$, we should expect to see some melting in hydrous cordierite-sapphirine assemblages at pressures above $7 \mathrm{~kb}$. The absence of any melting suggests that pressures were not much, if any, higher.

CONCLUSIONS The sapphirine bearing assemblage from Salvador, Bahia apparently formed at temperatures near $1000^{\circ} \mathrm{C}$ and pressures between 5 and $8 \mathrm{~kb}$ (depths of 15 to $24 \mathrm{~km}$ ). The formation of sapphirine from spinel and the subsequent reaction of sapphirine to cordierite were due to the addition of silica from surrounding quartzfeldspathic rocks to an aluminum-rich ultrabasic rock, a type of paragenesis which is common for sapphirine. Many new occurences should be found if regions of granulitic rocks (such as those of Brazil) are examined for locations where $\mathrm{Mg}$ and $\mathrm{Al}$ rich rocks could have been affected by silica metasomatism. Such sapphirine-bearing rocks can be useful in establishing temperatures of metamorphism, using the aluminum content of the orthopyroxene coexisting with the sapphirine as a geothermometer.

Acknowledgements I am very much indebted to Dr. Gilles Allard, who suggested this problem, provided the samples, and gave all the information on the field relationship. This work was prepared while I enjoyed the position of visiting professor in the Institute of Geociências, University of São Paulo and used the facilities of their microprobe laboratory. Financial support was also provided by the National Science Foundation (U.S.) through a grant to the University of Georgia.

\section{REFERENCES}

ALBEE, A. L. and RAY, L. - 1970 - Correction factors for electron probe microanalysis of silicates, oxides, carbonates, phosphates, and sulfates. Anal. Chem., 42: 382-403

ALLARD, G. O. and FUJIMORI, K. - 1966 - A new occurence of sapphirine in Salvador, Bahia, Brazil. (Abs.) Can. Mineral., 8: 660

ANASTASIOU, P. and SEIFERT, F. - 1972 - Solid solubility of $\mathrm{Al}_{2} \mathrm{O}_{3}$ in enstatite at high temperature and 1-5 kb water pressure. Contr. Mineral. and Petrol., 34: 272-281 
BIRD, G. W. and ANDERSON, G. M. - 1973 - The free energy of formation of magnesian cordierite and phlogopite. Am. J. Sci., 273: 84-91

CHATTERJEE, N.D. and SCHREYER, W. $-1972-$ The reaction enstatite + sillimanite $=$ $=$ sapphirine + quartz in the system $\mathrm{MgO}_{-} \mathrm{Al}_{2} \mathrm{O}_{3}-\mathrm{SiO}_{2}$. Contr. Mineral. and Petrol., 36: 49-62

DEER, W. A., HOWIE, R. A., and ZUSSMAN, J. - 1962 - Rockforming Minerals. Longmans, London, 5 vol.

FAWCETT, J. J. and YODER, H. S., Jr. - 1966 - Phase relationships of chlorites in the system $\mathrm{MgO}-\mathrm{Al}_{2} \mathrm{O}_{3}-\mathrm{SiO}_{2}-\mathrm{H}_{2} \mathrm{O}$. Am. Mineral, 51: 353-380

HERD, R. K., WINDLEY, B. F. and GHISLER, M. - 1969 - The mode of occurence and petrogenesis of the sapphirine-bearing and associated rocks of west Greenland. Gronl. Geol. Unders. Rapport. 24: 44 pp.

MENG, L. K. and MOORE, J. M., Jr. - 1972 - Sapphirine bearing rocks from Wilson Lake Labrador. Can. Mineral, 11: 777-790

MOORE, P. B. - 1969 - The crystal structure of sapphirine. Am. Mineral, 54: 31-49

MORSE, S. A. and TALLEY, S. H. - 1971 - Sapphirine reactions in deep-seated granulites near Wilson Lake, Central Labrador, Canada. Earth Planet. Sci. Latters, 10: 325-328

NEWTON, R. G. - 1972 - An experimental determination of the high-pressure stability limits of magnesian cordierite under wet and dry conditions. J. Geol., 80: 398-420

SCHREYER, W. and SELFERT, F. - 1969 - High pressure phases in the system $\mathrm{MgO}-\mathrm{Al}_{2} \mathrm{O}_{3}$ $-\mathrm{SiO}_{2}-\mathrm{H}_{2} \mathrm{O}$ : Am. J. Sci. Schairer Volume: 407-443

SCHREYER, W. and YODER, H.S. - 1964 - The system Mg-cordierite- $\mathrm{H}_{2} \mathrm{O}$ and related rocks. Neues Jarb: Mineralogie Abh., 101: 271-342

WILSON, A. F. and HUDSON, D. R. - 1967 - The discovery of beryllium bearing sapphirine in the granulites of the Musgrave ranges (Central Australia). Chem. Geol., 2, 209-215

WONES, D. R. and EUGSTER, H.P. - 1965 - Stability of biotite: experiment, theory, and application. Amer. Mineral., 50: 1 228-1 272

YODER, H. S. and EUGSTER, H. P. - 1954 - Phlogopite synthesis and stability range. Geochim. Cosmochim, Acta, 6: 157 